\title{
Effects of Specimen Size on The Compressive Strength of Rubber Modified Self-Compacting Concrete
}

\author{
Selim Cemalgil, Serkan Etli* \\ Munzur University, Department of Civil Engineering, Tunceli, Turkey \\ scemalgil@munzur.edu.tr $\mathrm{D}$, *serkanetli@munzur.edu.tr ${ }^{\mathrm{D}}$, \\ Received date:04.09.2020, Accepted date:24.12.2020
}

\begin{abstract}
In the studies carried out until today, rubber-modified self-compacting concretes (RMSCC) had been manufactured by replacing the aggregates of the waste vehicle tires (WVT) in the grain size distribution and particles that have different workability, different mechanical, and physical properties. However, variation of the carrying capacity of the RMSCC elements produced with different slenderness ratio $\mathrm{h} / \mathrm{b}$ ratio under axial load had not been researched in previous studies. Within the scope of this study, the change in physical and mechanical properties of RMSCC elements produced by using different $\mathrm{h} / \mathrm{b}$ ratios had been examined both experimentally and theoretically. Since the natural sand and WVT aggregate used in the production of concrete and their grain sizes are in the same range, WVT aggregate has been replaced by natural sand in 4 different proportions. These ratios were used as 5\%,10\%, 15\% and $20 \%$ of the natural sand volume, respectively. Slenderness ratios, $\mathrm{h} / \mathrm{b}$ ratios were 1.0, 1.5, 2.0, 2.5, 3.0 and 3.5, and experimental and theoretical investigations had been performed for 90 samples in total. The linear regression models of the obtained results had been analyzed and the equations with the $\mathrm{h} / \mathrm{b}$ ratios according to these models had been produced. The results of the obtained equations and the results of experimental axial pressure had been compared. In addition to the amount of WVT aggregate used and the increase in the ratio of $\mathrm{h} / \mathrm{b}$, the compressive strength losses had caused by different rates on the samples. The effect of the WVT aggregate ratio on the compressive strength had become more significant with the increase in use rate. Besides, regression analyzes had been performed to determine the effect of $\mathrm{h} / \mathrm{b}$ ratio on the compressive strength. In conclusion, regression $\mathrm{R}^{2}$ (coefficient of determination) values that belong to equations obtained had been found over 0.95.
\end{abstract}

Keywords: Mechanical properties, sample size effect, self-compacting concrete, tire rubber particles, waste management

\section{Numune Boyutunun Kauçukla Modifiye Edilmiş Kendiliğinden Yerleşen Betonun Basınç Dayanımı Üzerindeki Etkileri}

\begin{abstract}
Öz
Bugüne kadar yapılan çalışmalarda, tane boyutu dağılımındaki atık araç lastiklerinin (WVT) agregaları ve farklı işlenebilirliğe, farklı mekanik ve fiziksel özelliklere sahip partiküller değiştirilerek kauçuk modifiyeli kendinden yerleşen betonlar (RMSCC) imal edilmiştir. Ancak eksenel basınç altında farklı narinlik oranı $\mathrm{h} / \mathrm{b}$ ile üretilen RMSCC elemanlarının taşıma kapasitesindeki değişim daha önceki çalışmalarda araştırılmamıştı. Bu çalışma kapsamında farklı $\mathrm{h} / \mathrm{b}$ oranları kullanılarak üretilen RMSCC elemanlarının fiziksel ve mekanik özelliklerindeki değişim hem deneysel hem de teorik olarak incelenmiştir. Beton üretiminde kullanılan doğal kum ve WVT agregası tane boyutları aynı aralıkta olduğundan WVT agregası 4 farklı oranda doğal kum ile değiştirilmiştir. Bu oranlar doğal kum hacminin sırasıyla \%5, $\% 10, \% 15$ ve $\% 20$ 'si olarak kullanılmıştır. Narinlik oranları, h/b değerleri1.0, 1.5, 2.0, 2.5, 3.0 ve 3.5 olup, toplam 90 örnek için deneysel ve teorik araştırmalar yapılmıştır. Elde edilen sonuçların doğrusal regresyon modelleri incelenmiş ve bu modellere göre $\mathrm{h} / \mathrm{b}$ oranları ile denklemler üretilmiştir. Elde edilen denklemlerin sonuçları ve deneysel basınç dayanımı sonuçları karşılaştırılmıştır. Kullanılan WVT agregası miktarı ve h/b oranındaki artışın yanı sıra, numunelerde farklı oranlardan kaynaklanan basınç dayanımı kayıpları olmuştur. WVT agrega oranının basınç dayanımı üzerindeki etkisi, kullanım oranının artmasıyla daha da belirgin hale gelmiştir. Ayrıca h/b oranının basınç dayanımına etkisini belirlemek için regresyon analizleri yapılmıştır. Sonuç olarak elde edilen denklemlere ait $\mathrm{R}^{2}$ değerleri 0,95 'in üzerinde bulunmuştur.
\end{abstract}

Anahtar Kelimeler: Mekanik özellikler, numune boyut etkisi, kendiliğinden yerleşen beton, lastik kauçuk parçacıkları, atık yönetimi 


\section{INTRODUCTION}

The vehicle tires thrown into the waste fields constitute a large part of the solid wastes. These tires, which are stocked at waste sites, also pose various health risks, environmental and economic risks due to air, water, and soil pollution. Because of their unique shape and impermeable nature, when tires are accumulated in the collection areas, they cause the water to accumulate in the collection areas for a long time. This environment creates a reproductive habitat for mosquitoes and various pests. The easiest and cheapest removal method for tires is to burn them and this causes serious fire hazards. Furthermore, the dust remained after the waste tire burning pollutes the soil. Oil caused due to melt of tires may also contaminate soil and water. Approximately 1000 million tires reach the end of their useful lifetime each year. Currently there are 3000 million of stocked (whole tire) or ground filled (chopped tire) and 1000 millions of stocked (whole tire) or ground filled (chopped tire) in the USA. As a result, the disposal areas of waste tires create a significant danger that could lead to a reduction or even destruction of biodiversity (Sofi, 2018). When the data are analyzed, the problem of how to eliminate the waste tires together with the increase in the number of cars will arise (Fedroff et al., 2007; Karakurt et al., 2014).

Destruction or storage of waste tires leads to significant environmental problems. Generally waste tires or solid wastes are disposed by burning, burying or storing (Topçu and Eser, 2000; Al-Akhras and Smadi, 2004; Sukontasukkul and Chaikaew, 2006; Karakurt et al., 2014). In the United States, it has been stated that grinded car tires are mostly used in construction applications for sports field surfaces, asphalt production and ground filling (Rubber Manufacturers Association, 2006; Karakurt et al., 2014).Innovative solutions are needed in order to prevent problems caused due to waste vehicle tires (Li et al., 2004; Karakurt et al., 2014). In the early 1990s, tires used in extensive research projects had found use in different applications. Waste tires are also used as an asphalt and concrete aggregate due to its advantages such as low unit weight, insulating property, and high toughness.

In addition, waste tires are considered as shock absorbers on decks, breakwater, and railways. Besides these wastes are used for erosion control and they are used as highway barrier, swamp improvement, pavement sub-material in road fillings, modified material in hot mix asphalt pavements, seismic isolator in walkways and buildings (Topçu, 1995; Avcular and Topçu, 1997; Topçu and Avcular, 1997; Gönüllü, 2004; Turgut et al., 2007; Snelson et al., 2009; Sugözü, İlker, 2009; Koçak and Alpaslan, 2011). End of life tires are used for energy recycling in cement and power plants and, they are used in many areas as material recycle. According to the regulation published by Ministry of Environment and Urban Planning in Turkey (URL-1, 2006) on control of end of life tires (Control of End of Life Tires Regulation), manufacturers are responsible to collect the tires in related quota rate to be determined by considering the average tire abrasion rate of the Ministry of Environment and Urbanization and by taking account the tire tonnage in the market in previous year, to ensure the recycle or disposal of the amount collected and to document these procedures to the Ministry (Demirel, 2017).

According to data of the Ministry of Environment and Urbanization, between the years of 2007 and 2012 within the scope of Control of End of Life Tires Regulation there had been 337 thousand and 700 tons of end-of-life tires collected and approximately 210 thousand tons of these tires had been used in recycling plants for material recycle and approximately 140 thousand tons of them had been used in cement and energy plants for energy recycle. By the virtue of incentives, social responsibility projects and works of the Ministry, only in 2014120 thousand tons of end-of-life tires had been collected and recycled (URL-2, 2020). According to the data of the Association of Tire Industrialists (LASDER), by the end of the 2017, 765 tons of end-of-life tires had been recycled and it is expected that this amount will be 935 thousand tons by the end of 2018. In addition to this the number of recycling facilities were three in 2007 but it had stated that this number is currently reached to 24 (URL-3, 2018).

Self-compacting concrete (SCC) is a sophisticated high-performance concrete that has been defined as the most revolutionary step in concrete technology over the last 20 years due to its impact on economic and environmental sustainability in the construction sector (Figueiras et al., 2009; Hossain and Lachemi, 2009). It offers advantages like increase in construction speed in the field, reduction in manpower usage and elimination of noise and fuel consumption during the application of vibrator on concrete (EFNARC, 2005). When it is compared with 
normal concrete, it has the ability to fully compress itself under its own weight (Su et al., 2001; Domone, 2007; Felekoğlu et al., 2007; Nanthagopalan and Santhanam, 2009; Grdic et al., 2010) and it has high viscosity, filling rates, comfortable spreading in frequently reinforced areas and high weathering (Najim and Hall, 2012) resistance. In addition to these properties, high durability, low permeability and high compressive strength properties are among the advanced properties when compared to normal concrete (Khatib, 2008; Topçu et al., 2009; Wu et al., 2009). End of life tires is an innovative option with recycling, environmental, economic and performance benefits as an aggregate to produce a new class of concrete. The use of chopped and/or crumbed tire particles as a concrete aggregate exchange had been extensively examined by the researchers (it had summarized in a detailed review document (Najim and Hall, 2010)) and several recent studies had researched the effect of end of life tires when they are replaced with the sand in SCC (Bignozzi and Sandrolini, 2006; Garros et al., 2006; Turatsinze and Garros, 2008; Topçu and Bilir, 2009; Güneyisi, 2010; Najim and Hall, 2010; Uygunoğlu and Topçu, 2010). Due to high powder content of SCC, its microstructure is very compact and dense, and it results with high mechanical strength and brittle break modes. Therefore, selfcompacting rubber concrete (SCRC) composites can be used for applications that requires deformable (high ductility) concrete by using high flow and low/medium strength $(<35 \mathrm{MPa})$. Moreover, these concretes should be called green concrete because they are produced with environmentally friendly alternative aggregates. In infrastructure applications the compressive strength range is generally between 28 and $35 \mathrm{MPa}$. In applications such as bridge barriers and road foundations, high deformation and high toughness concrete is desirable, while> $35 \mathrm{MPa}$ compressive strength is not mandatory (Zheng et al., 2008). It is very easy for water to enter the concrete structure, which is open to the external environment and the cavity ratio is high, and the durability of the concrete is adversely affected from this (Atahan, 2002). From this point of view, the use of waste vehicle tires in concrete comes to the front as a convenient and sustainable method to remove damages on nature. However, when the studies in the literature are examined, it has been observed that waste vehicle tires can be used in certain proportions according to the grain size distribution (Bignozzi and Sandrolini, 2006; Aiello and Leuzzi, 2010; Rahman et al., 2012; Hilal, 2017).

Within the scope of this study, mechanical tests had been performed on 90 prismatic samples with cross-section of bxb and variable length ratios $h$ by using varying proportions of waste tire parts together with SCC. In this study, the relationship between $h / b$ ratio and waste tire parts ratios and their effects on mechanical and physical properties of the RMSCC elements had been investigated. Furthermore, it had been thought that the effect of dimensions can be reflected by using a formula with the help of non-linear regression models for each WVT aggregate ratio used and it had been aimed to obtain these formulas for the convenience of the user.

\section{MATERIAL AND METHODS}

Within the scope of this study, CEM-I 42.5R had used as cement, natural crushed stone had used as coarse aggregate (4/16) and natural sand (0/5.6) had used as sand in the preparation of the concrete mixtures. Information about the chemical and physical properties of the cement used had been given in Table 1. The mixtures of the aggregates had been tried to be brought closer to the Fuller curve by mixing in certain proportions. The specific gravity of the aggregates had been measured as 2.727 and 2.609 respectively for natural sand and natural crushed stone. Grain size distribution curves of aggregates had been given in Figure 1.

Table 1. Chemical compositions and physical properties of Portland cement.

\begin{tabular}{lc}
\hline Chemical analysis (\%) & Portland cement \\
\hline $\mathrm{CaO}$ & 63.57 \\
$\mathrm{SiO}_{2}$ & 19.54 \\
$\mathrm{Al}_{2} \mathrm{O}_{3}$ & 3.85 \\
$\mathrm{Fe}_{2} \mathrm{O}_{3}$ & 4.15 \\
$\mathrm{MgO}$ & 3.20 \\
$\mathrm{SO}_{3}$ & 2.86 \\
$\mathrm{~K}_{2} \mathrm{O}$ & 0.82 \\
$\mathrm{Na}_{2} \mathrm{O}$ & 0.39 \\
$\mathrm{Loss}$ on ignition & 1.62 \\
\hline Specific gravity $\left(\mathrm{g} \mathrm{cm}^{-3}\right)$ & 3.16 \\
\hline Fineness $\left(\mathrm{m}^{2} \mathrm{~kg}^{-1}\right)$ & $360^{*}$ \\
\hline
\end{tabular}

* Blaine specific surface area 


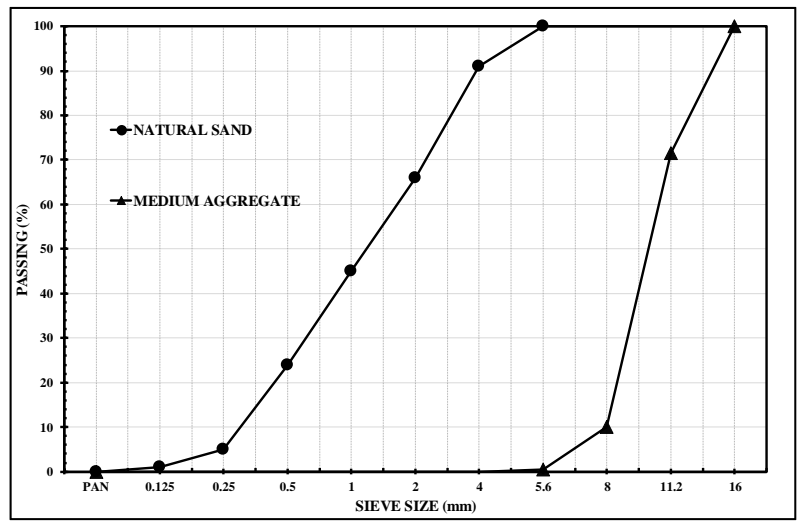

Figure 1. Sieve analysis of aggregates

The natural sand in the SCC is replaced by the WVT aggregate and the tire modified self-leveling concrete (RMSCC) has been obtained. The sand had been replaced with WVT aggregate volumetrically. WVT aggregate sizes had been found in the range of 0-4 $\mathrm{mm}$ (Figure 2) and specific gravity had been determined as 1.050. WVT aggregate had been changed with sand $5 \%, 10 \%, 15 \%$ and $20 \%$ by volume. To provide SCC properties, a high rate of water reducer (HRWR) based on Sika Visco Crete Hi-Tech-28 coded product with polycarboxylate had been used. The specific gravity of HRWR is calculated taken from producer as 1.055 . The design table of the SCC used in the study had been given in Table 2. The water/cement ratio had been taken as 0.35 . While preparing the mixtures, the dry mixture prepared with aggregate, cement and WVT aggregate had been mixed for 1 minute, then $2 / 3$ of the water had been mixed with HRWR, the remaining $1 / 3$ of the water had been added to the dry mixture at the end of the first minute and it had been stirred for 1 minute. Then, HRWR had been run by adding water in 1minute period (Figure 3 ). At the end of the period, the mixture had been allowed to stand for 1 minute then finally for a further 1 minute and the total preparation time had been 5 minutes. The compliance of the prepared mixtures with the SCC classification had been performed by slump flow and V-funnel (Figure 3 ) tests in the EFNARC (EFNARC, 2005) standard and it had been controlled by controlling the limiting values of the experiments. The properties of the fresh concrete mixture obtained had been given in Table 3 . Prepared fresh concrete mixtures had been placed in prismatic molds with $\mathrm{h} / \mathrm{b}$ ratios of $1.0,1.5,2.0,2.5$, 3.0 and 3.5 (Figure 4). The mixtures had been cured for 28 days at $20 \pm 2{ }^{\circ} \mathrm{C}$ in lime saturated water (Figure 3).

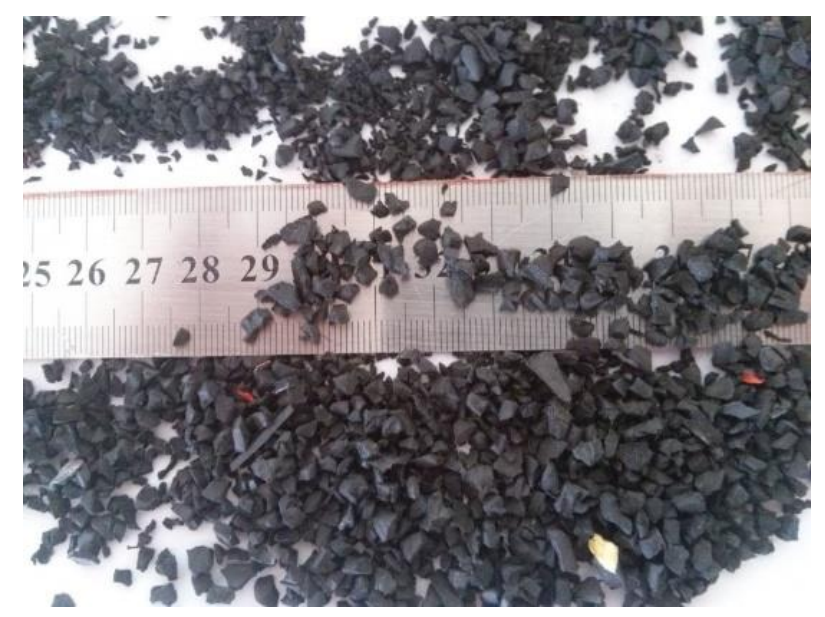

Figure 2. WVT aggregate size

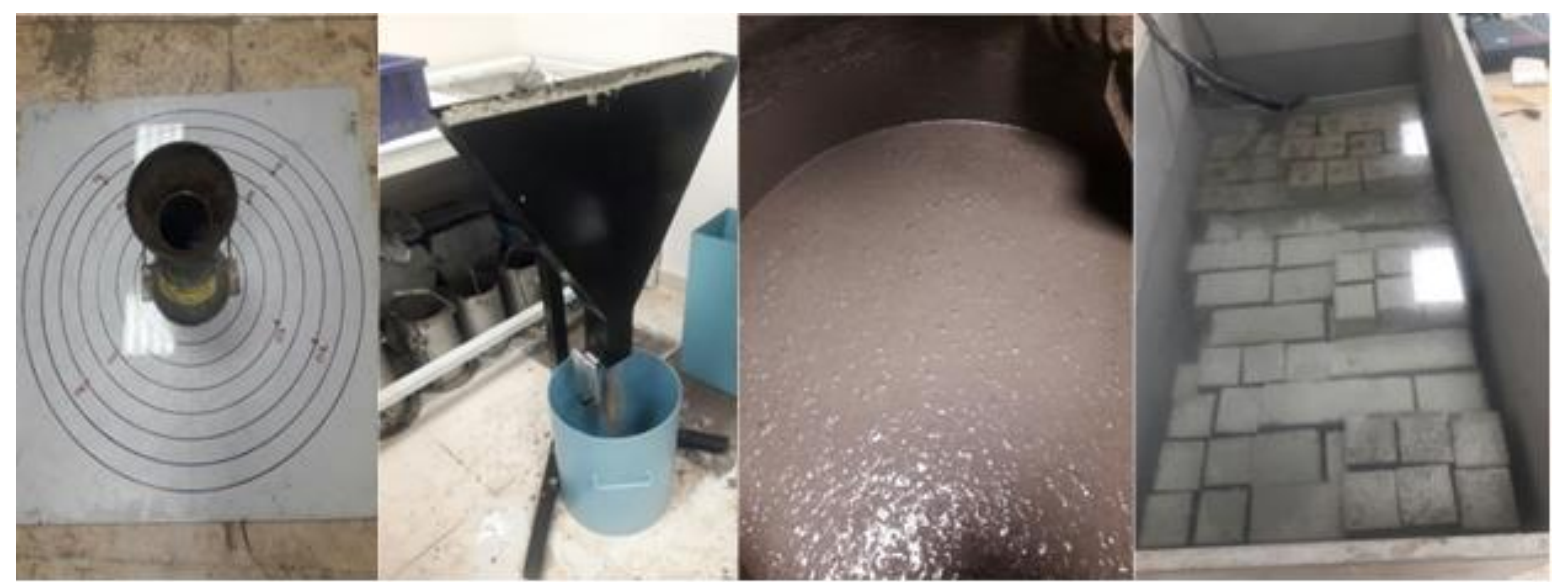

Figure 3. Experimental tests, fresh mix, and curing 
Table 2. Mix design of concrete samples $\left(\mathrm{kg} \mathrm{m}^{-3}\right)$

\begin{tabular}{ccccccc}
\hline Mix-ID & Cement & Water & HRWR & Rubber & Natural Sand & Medium Aggregate \\
\hline CONTROL & 600 & 210 & 9.6 & 0.00 & 719.20 & 840.98 \\
5\% WVT aggregate & 600 & 210 & 9.6 & 13.85 & 683.24 & 840.98 \\
10\% WVT aggregate & 600 & 210 & 9.6 & 27.69 & 647.28 & 840.98 \\
15\% WVT aggregate & 600 & 210 & 9.6 & 41.54 & 611.32 & 840.98 \\
20\% WVT aggregate & 600 & 210 & 9.6 & 55.38 & 575.36 & 840.98 \\
\hline
\end{tabular}

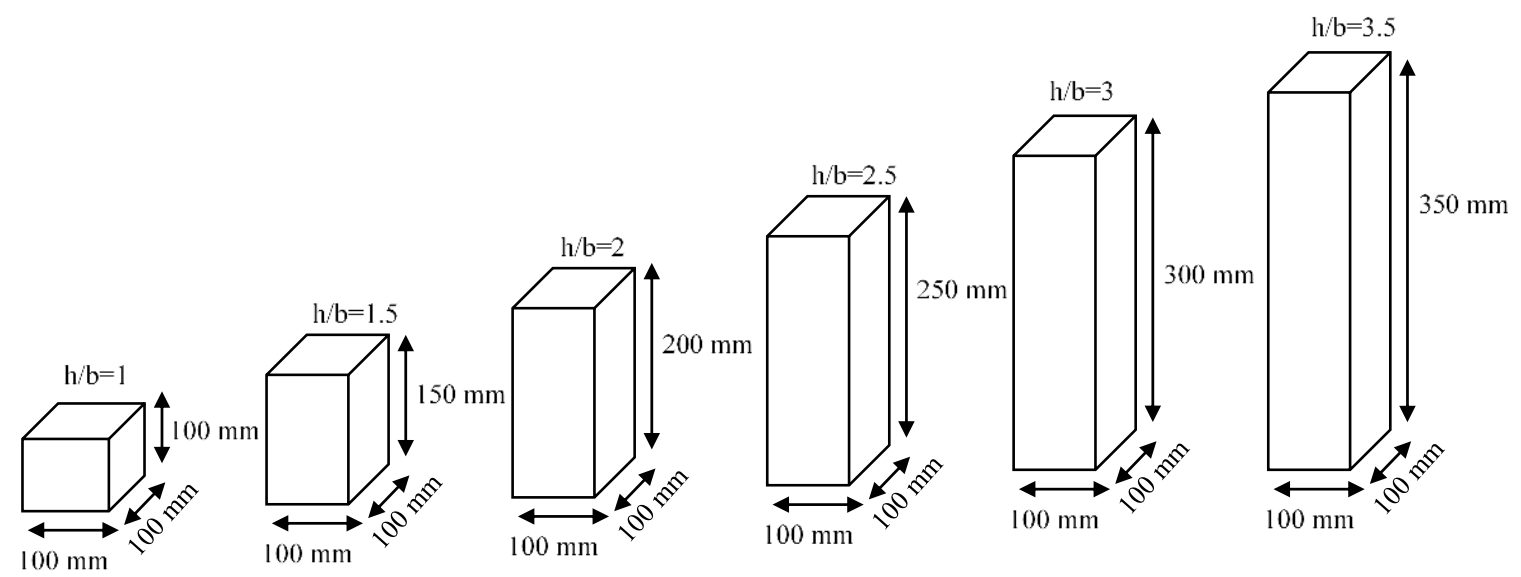

Figure 4. Schematic view of concrete sample according to $\mathrm{h} / \mathrm{b}$ ratios

\section{RESULT AND DISCUSSION Fresh Concrete Behavior}

Slump flow and V-funnel tests on fresh concrete were made according to EFNARC (EFNARC, 2005) standard to determine the viscosity and filling properties of the prepared concrete mixtures (Figure 3 ). The loss of cohesion and segregation in the obtained mixtures has been confirmed visually for each mixture (Figure 3 ). When the results given in Table 3 are considered, it is seen that the slump flow values are between $550-650 \mathrm{~mm}$ and this range is SF1 Slump-Flow (SF) classes for EFNARC (EFNARC, 2005) standard. With the help of the slump test of the fresh mix, many studies have been conducted to evaluate the RMSCC workability. Generally, researchers had been observed a significant reduction in workability (collapse) at some point as the content of rubber aggregates increased. The theorem assumes that this reduction may be due to the higher interparticle friction level between the rubber aggregate and the other mixture components (due to the surface structure of the rubber particles) and the total reduction in the unit weight of the plastic mixture
(Batayneh et al., 2008; Reda et al., 2008). These findings are generally consistent with some other studies (Cairns et al., 2004; Güneyisi et al., 2004; Hernández-Olivares and Barluenga, 2004; Albano et al., 2005; Gesoğlu and Güneyisi, 2007; Zheng et al., 2008; Guleria and Dutta, 2013), but the magnitude of the decrease depends on the size of the rubber and the percentage of change (Najim and Hall, 2010). As the ratio of WVT aggregate increases, it is observed that there is a decrease in the SF diameter in RMSCC (Table 3). For SCC mixtures, the T50 was recorded as the flow time when the fresh concrete reached the span of $500 \mathrm{~mm}$ after raising the slump cone (EFNARC, 2005). The results of the T50 slump flow tests showed that modified SCC containing 15\% rubber aggregate met the required downstream flow time ranging from $2 \mathrm{~s}$ to $5 \mathrm{~s}$. Moreover, when the viscosity class values are examined, it has observed that the T50 duration is greater than $2 \mathrm{~s}$ and the obtained v-funnel flow times are in the range of 8-25 sec (Table 3). These values have found to be VS2/VF2 viscosity classes for EFNARC (EFNARC, 2005) (Table 3). 
Table 3. Fresh properties of RMSCC

\begin{tabular}{ccccc}
\hline Mix-ID & ID & Slump Flow $(\mathrm{mm})$ & T $_{50}$ time $(\mathrm{sec})$ & V-funnel time $(\mathrm{sec})$ \\
\hline CONTROL & M1 & 648 & 2.8 & 9.1 \\
5\% WVT aggregate & M2 & 630 & 3.1 & 9.8 \\
10\% WVT aggregate & M3 & 620 & 3.6 & 11.5 \\
15\% WVT aggregate & M4 & 600 & 3.8 & 13.5 \\
20\% WVT aggregate & M5 & 585 & 4.0 & 15.2 \\
\hline
\end{tabular}

Table 4. Specific gravity of mix.

\begin{tabular}{ccccc}
\hline Mix-ID & Test-1 & Test-2 & Test-3 & Specific Gravity \\
\hline CONTROL & 2.248 & 2.260 & 2.262 & 2.257 \\
5\% WVT aggregate & 2.248 & 2.260 & 2.258 & 2.255 \\
10\% WVT aggregate & 2.169 & 2.236 & 2.256 & 2.220 \\
15\% WVT aggregate & 2.228 & 2.195 & 2.215 & 2.212 \\
20\% WVT aggregate & 2.200 & 2.201 & 2.203 & 2.201 \\
\hline
\end{tabular}

\section{Hardening Properties of Concrete}

After placing the fresh concrete mixtures into the molds in the laboratory, the water cured samples has been subjected to specific gravity, pressure, tensile and abrasion tests. In the density tests, $100 \times 100 \times 100$ $\mathrm{mm}$ cubic samples obtained from each mixture had been dried at the end of cure and their weights in water and their water saturated weights had been measured and then they had been dried for 24 hours at $110{ }^{\circ} \mathrm{C}$ in drying oven. The densities of the samples had been determined from the obtained values and they had been given in Table 4. With the increase of the WVT, the specific gravities decreased (Table 4).

Abrasion tests had been carried out for 3 minutes on each of the $100 \times 100 \times 100 \mathrm{~mm}$ cube samples had been produced for each mixture according to ASTM C-944 (American Society for Testing Materials, 2007) standard and for a total of 6 minutes and the results had been given in Table 5. Within the scope of this study abrasion tests in accordance with ASTM C944 (American Society for Testing Materials, 2007) had performed on $100 \times 100 \times 100 \mathrm{~mm}$ cube samples. A load of $98 \pm 1 \mathrm{~N}$, defined as a normal load in ASTM C944 (American Society for Testing Materials, 2007), was applied at a rate of $200 \mathrm{rpm}$ using a drill press. ACI defines the causes of abrasion on the concrete surface in four groups; due to human traffic, it is classified as abrasion on concrete floors, spiked tires and snow tire chains, abrasion due to vehicle traffic, abrasive materials in the water due to dam leaks, and high water velocities creating cavitations on the concrete surface (Oneill et al., 2001). In the scope of ASTM C944 Standard (American Society for Testing Materials, 2007), tests for the abrasion resistance of concrete had examined in two groups as one group is in terms of pedestrian traffic or light to medium weighted tire wheeled traffic and groups consisting of forklifts, heavy duty tire wheels, chain cars, heavy steel wheeled traffic or studded tires (Scott and Safiuddin, 2015). When the obtained results are examined, it had found that the loss of masses resulting from erosion with increasing WVT aggregate ratio in RMSCCs is gradually decreasing (Etli et al., 2018; Akgül et al., 2020). Increase in the WVT aggregate ratio had observed as a positive effect for SCC abrasion loss.

Tensile strength tests for bending are obtained as specified in ASTM C-496 (American Society for Testing Materials, 2007) and it had been given in Table 6. The compressive strength tests had been carried out with 3 samples per $\mathrm{h} / \mathrm{b}$ ratio.

Within the scope of the study, the variation capacity of the samples of RMSCCs prepared by WVT aggregate with different ratios under axial pressure had been researched with the effect of increase in the sample slenderness ratio. The prismatic samples prepared from each of the mixtures with $1,1.5,2.0,2.5,3.0$ and 3.5 prepared for this purpose had been subjected to axial pressure with a loading rate of $1.5 \mathrm{kN} \mathrm{s}^{-1}$. The cross-sections (bxb) of all produced samples had been chosen to be $100 \times 100$ $\mathrm{mm}$ and thus it had foreseen that they can be compared with the pressure samples with standard sample sizes $(100 \times 100 \times 100 \mathrm{~mm})$ used in the experiments. The results of the obtained axial pressure values had given in Table-7. When the 
compressive strengths of $100 \times 100 \times 100 \mathrm{~mm}$ cube samples obtained from the mixtures were examined at the end of 28 days cure, it is observed that their compressive strengths ranged from 39 to $55 \mathrm{MPa}$ (Table 6). All concrete mixtures had exceeded the minimum strength $(17 \mathrm{MPa})$ for structural concrete (Neville and Brooks, 2010). Mixtures containing 20\% by volume of WVT aggregate are suitable for making structural concrete mixtures in terms of compressive strength and meet the target of 28-35 MPa pressure strength range required for civilian infrastructure applications, which is another application parameter
(Zheng et al., 2008). As you will guess when the WVT aggregate substitution rate increased, the compressive strengths gradually decreased in the RMSCC mixtures (Table 6).

While $\mathrm{h} / \mathrm{b}$ ratio increases, compressive strength values in each group decreases (Table 7). A visual evaluation of the pressure changes with dimension effect in RMSCC had applied in Figure-5. Furthermore, when the $\mathrm{R}^{2}$ values of the change are compared with the selected $\mathrm{h} / \mathrm{b}$ ratios, the $\mathrm{R}^{2}$ values of the obtained results are greater than 0.95 and it is acceptable (Figure 5).

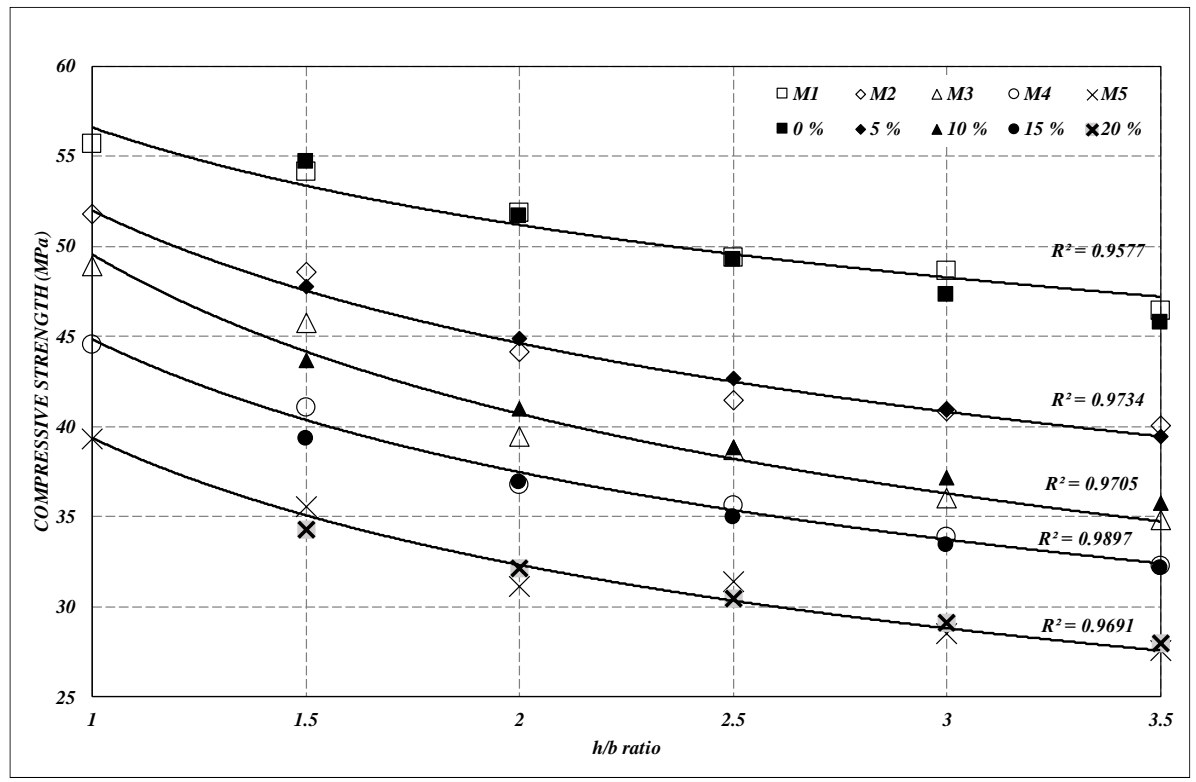

Figure 5. Compressive strength changes with $\mathrm{h} / \mathrm{b}$ ratio

Table 5. Abrasion resistance test results.

\begin{tabular}{ccccc}
\hline Mix-ID & Test-1 & Test-2 & Test-3 & Abrasion loss (\% wt) \\
\hline CONTROL & 0.0667 & 0.0629 & 0.0649 & 0.0648 \\
5\% WVT aggregate & 0.0622 & 0.0639 & 0.0635 & 0.0632 \\
10\% WVT aggregate & 0.0571 & 0.0582 & 0.0577 & 0.0577 \\
15\% WVT aggregate & 0.0525 & 0.0512 & 0.0523 & 0.0520 \\
20\% WVT aggregate & 0.0490 & 0.0486 & 0.0478 & 0.0484 \\
\hline
\end{tabular}

Table 6. Compressive and tensile strength test results.

\begin{tabular}{cccc|cc}
\hline & & & & \multicolumn{2}{c}{$\sigma_{(\text {ave })}(\mathrm{MPa})$} \\
Mix-ID & Test-1 & Test-2 & Test-3 & Tension & 7.87 \\
\hline CONTROL & 7.58 & 8.03 & 7.99 & 7.12 & 55.67 \\
5\% WVT aggregate & 7.13 & 6.96 & 7.29 & 6.81 & 48.91 \\
10\% WVT aggregate & 6.97 & 7.01 & 6.47 & 6.62 & 44.56 \\
15\% WVT aggregate & 6.21 & 6.67 & 6.98 & 5.25 & 39.33 \\
\hline
\end{tabular}


Table 7. Compressive strength test results for mixes.

\begin{tabular}{|c|c|c|c|c|c|c|c|c|}
\hline \multirow{2}{*}{ ID } & \multirow{2}{*}{$\mathrm{b}(\mathrm{mm})$} & \multirow{2}{*}{$\mathrm{h}(\mathrm{mm})$} & \multirow{2}{*}{$h / b$} & \multicolumn{4}{|c|}{ Compressive strength (MPa) } & \multirow[b]{2}{*}{ Std Dev } \\
\hline & & & & Test-1 & Test-2 & Test-3 & Mean & \\
\hline \multirow{6}{*}{ M1 } & 100 & 100 & 1.00 & 55.31 & 56.46 & 55.25 & 55.67 & 0.56 \\
\hline & 100 & 150 & 1.50 & 53.39 & 54.59 & 54.51 & 54.16 & 0.55 \\
\hline & 100 & 200 & 2.00 & 52.7 & 51.2 & 51.72 & 51.87 & 0.62 \\
\hline & 100 & 250 & 2.50 & 51.06 & 50.26 & 46.84 & 49.39 & 1.83 \\
\hline & 100 & 300 & 3.00 & 46.90 & 51.02 & 47.99 & 48.64 & 1.74 \\
\hline & 100 & 350 & 3.50 & 45.58 & 47.91 & 45.83 & 46.44 & 1.04 \\
\hline \multirow{6}{*}{ M2 } & 100 & 100 & 1.00 & 52.33 & 51.21 & 51.77 & 51.77 & 0.46 \\
\hline & 100 & 150 & 1.50 & 48.20 & 48.71 & 48.89 & 48.60 & 0.29 \\
\hline & 100 & 200 & 2.00 & 43.86 & 44.43 & 44.12 & 44.14 & 0.23 \\
\hline & 100 & 250 & 2.50 & 41.94 & 41.63 & 40.87 & 41.48 & 0.45 \\
\hline & 100 & 300 & 3.00 & 40.66 & 41.67 & 40.30 & 40.87 & 0.58 \\
\hline & 100 & 350 & 3.50 & 39.18 & 40.61 & 40.40 & 40.06 & 0.63 \\
\hline \multirow{6}{*}{ M3 } & 100 & 100 & 1.00 & 48.29 & 49.48 & 48.98 & 48.91 & 0.49 \\
\hline & 100 & 150 & 1.50 & 44.42 & 46.90 & 45.91 & 45.74 & 1.02 \\
\hline & 100 & 200 & 2.00 & 38.66 & 39.61 & 40.01 & 39.43 & 0.57 \\
\hline & 100 & 250 & 2.50 & 40.11 & 38.61 & 37.42 & 38.72 & 1.1 \\
\hline & 100 & 300 & 3.00 & 36.97 & 35.31 & 35.86 & 36.05 & 0.69 \\
\hline & 100 & 350 & 3.50 & 35.89 & 33.70 & 34.89 & 34.83 & 0.9 \\
\hline \multirow{6}{*}{ M4 } & 100 & 100 & 1.00 & 44.39 & 44.98 & 44.32 & 44.56 & 0.3 \\
\hline & 100 & 150 & 1.50 & 40.43 & 41.73 & 40.99 & 41.05 & 0.53 \\
\hline & 100 & 200 & 2.00 & 36.76 & 36.77 & 36.82 & 36.78 & 0.03 \\
\hline & 100 & 250 & 2.50 & 36.73 & 36.15 & 34.06 & 35.65 & 1.15 \\
\hline & 100 & 300 & 3.00 & 35.02 & 33.88 & 32.66 & 33.85 & 0.96 \\
\hline & 100 & 350 & 3.50 & 32.04 & 30.41 & 34.38 & 32.27 & 1.63 \\
\hline \multirow{6}{*}{ M5 } & 100 & 100 & 1.00 & 37.01 & 41.12 & 39.86 & 39.33 & 1.72 \\
\hline & 100 & 150 & 1.50 & 35.82 & 34.11 & 36.76 & 35.56 & 1.1 \\
\hline & 100 & 200 & 2.00 & 31.26 & 30.95 & 31.23 & 31.15 & 0.14 \\
\hline & 100 & 250 & 2.50 & 30.94 & 32.36 & 30.80 & 31.37 & 0.7 \\
\hline & 100 & 300 & 3.00 & 29.71 & 27.60 & 28.25 & 28.52 & 0.88 \\
\hline & 100 & 350 & 3.50 & 27.20 & 28.74 & 26.81 & 27.58 & 0.83 \\
\hline
\end{tabular}

To examine the distribution of WVT aggregate in the produced samples, the concrete samples had obtained by dividing the concrete samples with concrete pressure test press and these samples had shown in Figure 6. When the cross-sections are examined, it is seen that WVT aggregate is distributed very homogeneously in RMSCC. In addition, when the figures are examined carefully, it is observed that the coarse pieces are mostly broken off and separated from the other surface, namely, there is sufficient adherence between the cement paste and WVT aggregate. In Figure 7 the post-fracture figures of the samples with varying $h / b$ ratio and WVT aggregate ratio under axial pressure had been shown. When the Figure 7 is examined, it has observed that fractures are more severe in the SCC that spilled for control and while fractures in RMSCCs are observed less severe with the increase in WVT aggregate ratio. In addition, the fracture shapes also started with the tapered prism shape in the samples with a ratio of $h / b$ as expected with the change of the $\mathrm{h} / \mathrm{b}$ ratio, and with the increase in the refractive angle, it results in $90^{\circ}$ as half-split in the samples with $\mathrm{h} / \mathrm{b}$ ratio 3.5 .

The aim of this study is to experimentally investigate the properties of axial compressive strength of concrete and to propose equations for estimating compressive strength by sample size, sample shape and placement direction based on fracture mechanics. In addition, a mutual relationship between these equations has been evaluated. Based on the magnitude effect law (SEL) derived by Bazant (Bažant, 2009), Kim and Eo (Kim, 2009) proposed a modified magnitude effect law (MSEL) by adding independent magnitude to predict the SEL. 

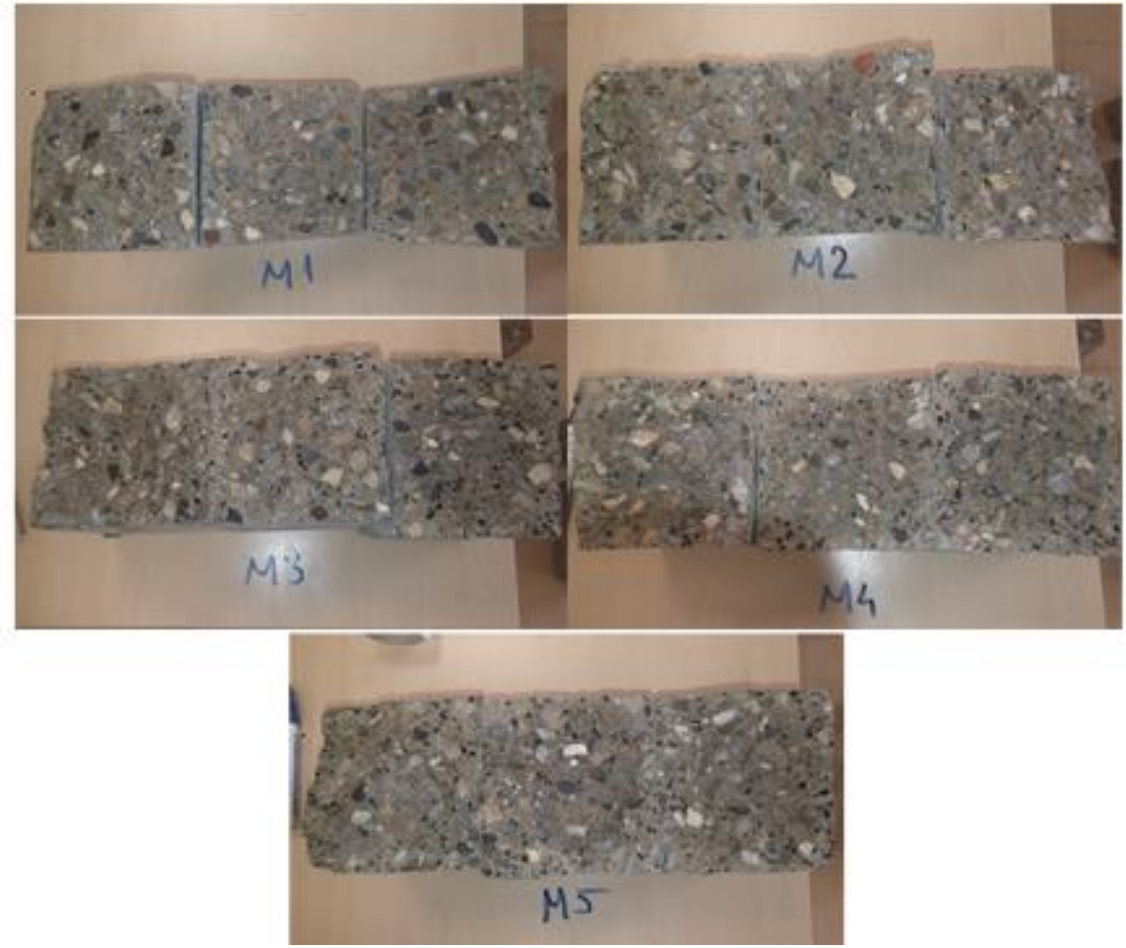

Figure 6. Middle section of samples.
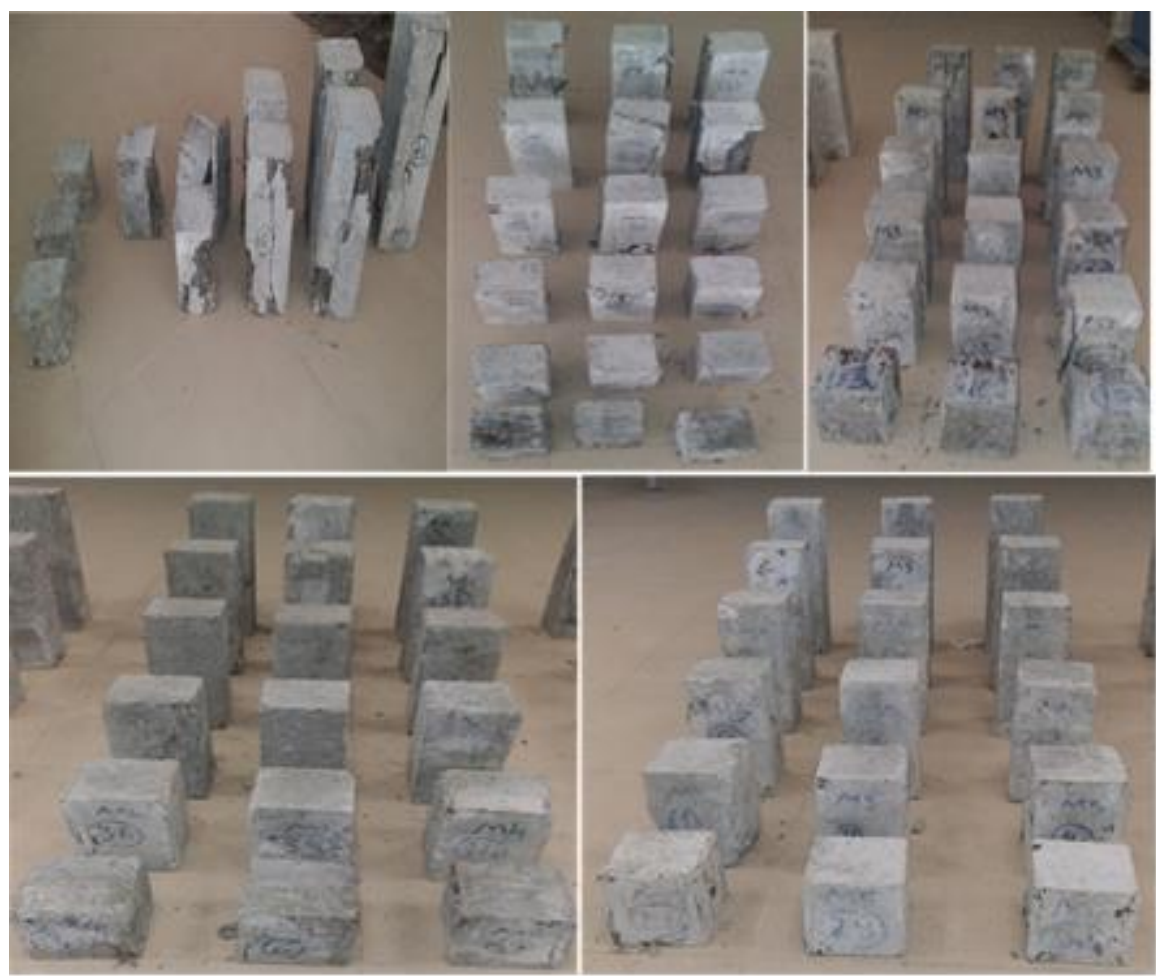

Figure 7. Prismatic samples 
This concept was developed in the next studies and the equation (1) was obtained. This equation had been proposed to obtain the compressive strength of cylindrical concrete samples having various and height/diameter ratios (Kim et al., 1999). For this purpose, the effects of maximum aggregate size on fracture zone (FPZ) had taken into consideration and the characteristic length concept had introduced. In the study, the number of samples with the $\mathrm{h} / \mathrm{d}$ ratio and the samples with $\mathrm{h} / \mathrm{d}=2.0$ were 222 and 456 , respectively. The equation of the characteristic length determination method is derived by Kim and Eo (Kim, 2009) and had described as in Equation 1.

$\sigma_{n}(h, d)=\frac{0.4 \times f_{c}}{\sqrt{1+(h-d) / 5}}+0.8 \times f_{c}$

Where the compressive strength of standard cylinder is defined as fc, height of cylinder specimen is defined as $\mathrm{h}$ and diameter of cylinder specimen $\mathrm{d}$ are in $\mathrm{cm}$. Equation 1 was developed by the researchers and the equation for the prism samples had proposed in Equation 2 (Seong-Tae et al., 2006);

$\mathrm{f}_{\mathrm{pr}}(\mathrm{d})=\frac{1.02 \times \mathrm{f}_{\mathrm{c}}}{\sqrt{1+\mathrm{d} / 2.6}}+0.52 \times \mathrm{f}_{\mathrm{c}}$

Where compressive strength with size of prisms $\mathrm{f}_{\mathrm{pr}}(\mathrm{d})$ and compressive strength $\mathrm{fc}$ are in $\mathrm{MPa}$ and the smallest size of the prism $\mathrm{d}$ is in $\mathrm{cm}$. The experimental data in this study were evaluated and the Equation 2 was re-adapted for this study. Furthermore, since $\mathrm{R}^{2}$ values are appropriate for SCC and RMSCC, the main form of the obtained formulas according to $h / b$ ratio changes had given as in Equation 3.

$\mathrm{f}_{\mathrm{pr}}(\mathrm{h} / \mathrm{b})=\frac{\mathrm{f}_{\mathrm{c}}}{\sqrt{1+\mathrm{h} / \mathrm{b}}}+\alpha_{i} \times \mathrm{f}_{\mathrm{c}}$

Where compressive strength with size of prisms $\mathrm{f}_{\mathrm{pr}}(\mathrm{h} / \mathrm{b})$ and compressive strength $\mathrm{fc}$ are in MPa and the aspect ratio of sample is $\mathrm{h} / \mathrm{b}$. In the above formula, the $\alpha_{\mathrm{i}}$ values to be written are given as $0.35,0.29$, $0.26,0.25$, and 0.24 , respectively, for the SCC spilled for control and 5\%,10\%, 15\% and 20\% WVT aggregate for the added RMSCC. The comparison of the results with the formulas had given in Figure 5.

\section{CONCLUSION}

This article presents the results of an experimental study on designed WVT aggregated prism concrete specimens, where the effect of sample sizes (in prism specimens for varying $\mathrm{h} / \mathrm{b}$ ratios) on compressive strength was investigated. Since there is no correlation between the compressive strength of the prismatic and cubic specimens of RMSCCs in the literature, a model based on the literature is validated by linear regression showing the relationships between 28-day compressive strength. The results show that the average 28-day compressive strength of the cubic shape is always higher than its prismatic counterpart.

It is found that there is no problem in terms of fresh concrete properties when appropriate sized WVT aggregate parts are used, and they are replaced with the sand in SCC (self-compacting concrete) up to substitute ratio of $20 \%$. However, compressive strengths obtained because of the increase of the WVT aggregate particles used are diverging from the SCC main design. In the obtained formulas, reason for the decrease in the correction coefficients used with the increased WVT ratio is probably caused due to increase in the dominance of WVT aggregate particles under the axial load. By the simple formulas obtained it is possible to calculate axial compressive strengths for RMSCC of the sample sized elements to be produced.

\section{CONFLICT OF INTEREST STATEMENT}

The authors declare that there is no conflict of interest.

\section{RESEARCH AND PUBLICATION ETHICS STATEMENT}

The authors declare that research and publication ethics are followed in this study.

\section{REFERENCES}

Aiello, M.A., Leuzzi, F., 2010. Waste tyre rubberized concrete:Properties at fresh and hardened state. Waste Management, 30(8-9):1696-1704.

Akgül, M., Doğan, O., Etli, S., 2020. Farklı çimento ile üretilen granül atık kauçuk agregaların ikame edilmiş kendiliğinden yerleşen beton harcının mekanik özelliklerinin incelenmesi. Uluslararası Mühendislik Araştırma ve Geliştirme Dergisi, 12(2):787-798.

Al-Akhras, N.M., Smadi, M.M., 2004. Properties of tire rubber ash mortar. Cement and Concrete Composites, 26(7):821-826.

Albano, C., Camacho, N., Reyes, J., Feliu, J.L., Hernández, M., 2005. Influence of scrap rubber addition to Portland I concrete 
composites:Destructive and non-destructive testing. Composite Structures, 71(3-4):439-446.

American Society for Testing Materials., 2007. Standard Test Method for Abrasion Resistance of concrete or Mortar Surfaces by the Rotating-Cutter Method. ASTM C944.

Atahan, H.N., 2002. Düşük su/çimento oranlı betonlarda özelliklerin çimento hamurun boşluk yapısına duyarlılığı. Doktora Tezi, İTÜ Fen Bilimleri Enstitüsü, İstanbul.

Avcular, N., Topçu, İ.B., 1997. Analysis of rubberized concrete as a composite material. Cement and Concrete Research, 27(8):1135-1139.

Batayneh, M.K., Marie, I., Asi, I., 2008. Promoting the use of crumb rubber concrete in developing countries. Waste Management, 28(11):2171-2176.

Bažant, Z.P., 2009. Size Effect in Blunt Fracture:Concrete, Rock, Metal. Journal of Engineering Mechanics, 110(4):518-535.

Bignozzi, M.C., Sandrolini, F., 2006. Tyre rubber waste recycling in self-compacting concrete. Cement and Concrete Research, 36(4):735-739.

Cairns, R.A., Hew, H.Y., Kenny, M.J., 2004. The use of recycled rubber tyres in concrete construction. Sustainable Waste Management and Recycling, 135-142.

Demirel, N., 2017. Ömrünü Tamamlamış Araçların Geri Dönüşümünde Yükseltilmiş Yönetmelik Hedeflerini Karşılamak İçin A $\breve{g}$ Tasarımı ve Modellenmesi. Gazi Üniversitesi Fen Bilimleri Dergisi Part C:Tasartm ve Teknoloji, 5(3):223-236.

Domone, P.L., 2007. A review of the hardened mechanical properties of self-compacting concrete. Cement and Concrete Composites, 29(1):1-12.

EFNARC., 2005. The European Guidelines for SelfCompacting Concrete:Specification, Production and Use. The European Guidelines for Self Compacting Concrete, 68.

Etli, S., Cemalgil, S., Onat, O., 2018. Mid-Temperature Thermal Effects on Properties of Mortar Produced with Waste Rubber as Fine Aggregate. International Journal of Pure and Applied Sciences, 4(1):10-22.

Fedroff, D., Ahmad, S., Savas, B., 2007. Mechanical Properties of Concrete with Ground Waste Tire Rubber. Transportation Research Record:Journal of the Transportation Research Board, 1532(1532):66-72.

Felekoğlu, B., Türkel, S., Baradan, B., 2007. Effect of water/cement ratio on the fresh and hardened properties of self-compacting concrete. Building and Environment, 42(4):1795-1802.

Figueiras, H., Nunes, S., Coutinho, J.S., Figueiras, J., 2009. Combined effect of two sustainable technologies:Self-compacting concrete (SCC) and controlled permeability formwork (CPF). Construction and Building Materials, 23(7):25182526.

Garros, M., Turatsinze, A., Granju, J., 2006. Effect of Rubber Aggregates from Grinding of End-of-Life Tires on the Properties of SCC. Special Publication 235, 177-188.

Gesoğlu, M., Güneyisi, E., 2007. Strength development and chloride penetration in rubberized concretes with and without silica fume. Materials and Structures/Materiaux et Constructions, 40(9):953964.

Gönüllü, M.T., 2004. Atik Lastiklerin Yönetimi. Katı Atık Geri Dönüşüm Teknolojileri Semineri, İstanbul Sanayi Odast, Ístanbul, .

Grdic, Z.J., Toplicic-Curcic, G.A., Despotovic, I.M., Ristic, N.S., 2010. Properties of self-compacting concrete prepared with coarse recycled concrete aggregate. Construction and Building Materials, 24(7):1129-1133.

Guleria, S.P., Dutta, R.K., 2013. Rubberized portland cement concrete. Journal of GeoEngineering, $8(2): 33-40$.

Güneyisi, E., 2010. Fresh properties of self-compacting rubberized concrete incorporated with fly ash. Materials and Structures/Materiaux et Constructions, 43(8):1037-1048.

Güneyisi, E., Gesoğlu, M., Özturan, T., 2004. Properties of rubberized concretes containing silica fume. Cement and Concrete Research, 34(12):2309-2317.

Hernández-Olivares, F., Barluenga, G., 2004. Fire performance of recycled rubber-filled high-strength concrete. Cement and Concrete Research, 34(1): 109-117.

Hilal, N.N., 2017. Hardened properties of selfcompacting concrete with different crumb rubber size and content. International Journal of Sustainable Built Environment, 6(1):191-206.

Hossain, K.M.A., Lachemi, M., 2009. Fresh, Mechanical, and Durability Characteristics of SelfConsolidating Concrete Incorporating Volcanic Ash. Journal of Materials in Civil Engineering, 22(7):651-657.

Karakurt, C., Işıkdăg, B., Topçu, İ.B., 2014. Atık Lastik Agregalı Harçların Mekanik ve Fiziksel Özelliklerinin İncelenmesi. Politeknik Dergisi, 17(1):3-7.

Khatib, J.M., 2008. Performance of self-compacting concrete containing fly ash. Construction and Building Materials, 22(9):1963-1971.

Kim, J.K., 2009. Size effect in concrete specimens with dissimilar initial cracks. Magazine of Concrete Research, 42(153):233-238. 
Kim, J.K., Yi, S.T., Park, C.K., Eo, S.H., 1999. Size effect on compressive strength of plain and spirally

reinforced concrete cylinders. ACI Structural Journal, 96(1):88-94.

Koçak, Y., Alpaslan, L., 2011. Atık Lastiklerin Çimento ve Beton Sektöründe Kullanım Potansiyelleri. In İnternational Advanced Technologies Symposium p. 118-122.

Li, G., Stubblefield, M.A., Garrick, G., Eggers, J., Abadie, C., Huang, B., 2004. Development of waste tire modified concrete. Cement and Concrete Research, 34(12):2283-2289.

Najim, K.B., Hall, M.R., 2010. A review of the fresh/hardened properties and applications for plain(PRC) and self-compacting rubberised concrete (SCRC). Construction and Building Materials, 24(11):2043-2051.

Najim, K.B., Hall, M.R., 2012. Mechanical and dynamic properties of self-compacting crumb rubber modified concrete. Construction and Building Materials, 27(1):521-530.

Nanthagopalan, P., Santhanam, M., 2009. Experimental investigations on the influence of paste composition and content on the properties of Self-Compacting Concrete. Construction and Building Materials, 23(11):3443-3449.

Neville, A.M., Brooks, J.J., 2010. Properties of concrete. Building and Environment, 11:442.

Oneill, R.C., Hill, R.L., Butler, W.B., Cabrera, J.G., Carrasquillo, R.L., Ellis Jr, W.E., Eriin, B.E., Fidjestal, P., Forster, S.W., Gordon, C., 2001. Guide to durable concrete. ACI201, 2:2-5.

Rahman, M.M., Usman, M., Al-Ghalib, A.A., 2012. Fundamental properties of rubber modified selfcompacting concrete (RMSCC). Construction and Building Materials, 36:630-637.

Reda, T.M.M., El-Dieb, A.S., Abd El-Wahab, M.A., Abdel-Hameed, M.E., 2008. Mechanical, Fracture, and Microstructural Investigations of Rubber Concrete. Journal of Materials in Civil Engineering, 20(10):640649.

Rubber Manufacturers Association., 2006. Scrap tire markets in the United States. Washington, DC,

Scott, B.D., Safiuddin, M., 2015. Abrasion Resistance of Concrete - Design, Construction and Case Study. ISSR Journals, 6(3):136-148.

Seong-Tae, Y., Eun-Ik, Y., Joong-Cheol, C., 2006. Effect of specimen sizes, specimen shapes, and placement directions on compressive strength of concrete. Nuclear Engineering and Design, 236(2):115-127.

Snelson, D.G., Kinuthia, J.M., Davies, P.A., Chang, S.R., 2009. Sustainable construction:Composite use of tyres and ash in concrete. Waste Management, 29(1):360367.
Sofi, A., 2018. Effect of waste tyre rubber on mechanical and durability properties of concrete - A review. Ain Shams Engineering Journal, 9(4):2691-2700.

Su, N., Hsu, K.C., Chai, H.W., 2001. A simple mix design method for self-compacting concrete. Cement and Concrete Research, 31(12):1799-1807.

Sugözü, İ., 2009. Atık taşıt lastikleri ve değerlendirme yöntemleri. Taşıt Teknolojileri Elektronik Dergisi, 1(1):35-46.

Sukontasukkul, P., Chaikaew, C., 2006. Properties of concrete pedestrian block mixed with crumb rubber. Construction and Building Materials, 20(7):450-457.

Topçu, İ.B., 1995. The properties of rubberized concretes. Cement and Concrete Research, 25(2):304-310.

Topçu, İ.B., Avcular, N., 1997. Collision Behaviours of Rubberized Concrete. Cement and concrete research, 27(12):11.

Topçu, İ.B., Bilir, T., 2009. Experimental investigation of some fresh and hardened properties of rubberized selfcompacting concrete. Materials and Design, 30(8):3056-3065.

Topçu, İ.B., Bilir, T., Uygunoğlu, T., 2009. Effect of waste marble dust content as filler on properties of selfcompacting concrete. Construction and Building Materials, 23(5):1947-1953.

Topçu, İ.B., Eser, Ö.F., 2000. Lastik Agregalı Betonlarin Özelikleri. Balıkesir Üniv., Müh.-Mim. Fak., III. Balıkesir Müh.-Mim. Semp., 173-181.

Turatsinze, A., Garros, M., 2008. On the modulus of elasticity and strain capacity of Self-Compacting Concrete incorporating rubber aggregates. Resources, Conservation and Recycling, 52(10):1209-1215.

Turgut, P., Yeşilata, B., Işıker, Y., 2007. Kompozit Yapı Malzemelerinde Isıl Özellik Ölçümü-2:Hurda Lastik Katkılı Betonlar için Ölçüm Sonuçları. Mühendis ve Makina, 48(565):33-39.

URL-1, 2006. http://www.resmigazete.gov.tr/eskiler/ 2006/11/20061125-2.htm.

URL-2, 2020. http://atiksahasi.com/Atik-LastiklerinOm runu-Tamamlamis-Lastikler-Geri-DonusumSektoru n deki-Onemi-38, 12 August 2020.

URL-3, 2018. http://www.lasder.org.tr/.

Uygunoğlu, T., Topçu, İ.B., 2010. The role of scrap rubber particles on the drying shrinkage and mechanical properties of self-consolidating mortars. Construction and Building Materials, 24(7):1141-1150.

Wu, Z., Zhang, Y., Zheng, J., Ding, Y., 2009. An experimental study on the workability of selfcompacting lightweight concrete. Construction and Building Materials, 23(5):2087-2092.

Zheng, L., Sharon Huo, X., Yuan, Y., 2008. Experimental investigation on dynamic properties of rubberized concrete. Construction and Building Materials, 22(5):939-947. 